\title{
Collaborative Governance of the Presidential Advisory Council from the Dynamic Governance Perspective
}

\author{
Adhianti $^{1}$, Lisman Manurung ${ }^{2}$, Roy Valiant Salomo ${ }^{3}$, Linda Darmajanti ${ }^{4}$ \\ poppy.adhianti@gmail.com¹, lisman.manurung@gmail.com², roy.v09@ui.ac.id², \\ lindib_204la@yahoo.com ${ }^{4}$ \\ Ministry of State Secretariat of the Republic of Indonesia, Jakarta 10110, Indonesia ${ }^{1}$ \\ Department of Public Administration, Faculty of Administrative Sciences, \\ Universitas Indonesia, Depok 16424, Indonesia ${ }^{2}$ \\ Department of Public Administration, Faculty of Administrative Sciences, \\ Universitas Indonesia, Depok 16424, Indonesia ${ }^{3}$ \\ Department of Sociology, Faculty of Social and Political Sciences, \\ Universitas Indonesia. Depok 16424, Indonesia ${ }^{4}$
}

\begin{abstract}
This study aims to analyze the organizational capabilities of the Presidential Advisory Council (Wantimpres), analyze the dynamics of collaborative governance[1] Wantimpres, and design the collaborative governance of Wantimpres from the perspective of Dynamic Governance[2]. The results showed that the absence of the fields of the members of the Wantimpres in the President Joko Widodo's era made the limited advice and consideration needed by the President. The Wantimpres Secretariat is deemed unable to meet the needs of think tanks and has not been able to fully facilitate Wantimpres activities. So, it is necessary to optimize the role of stakeholders in collaborative governance at the Wantimpres. In the process of collaboration also requires alignment with relevant stakeholders, and engagement must be created in an effort to formulate advice and consideration to the quality President through the collaborative governance design of the dynamic governance perspective.
\end{abstract}

Keywords: collaborative governance, dynamic governance, presidential advisory council.

\section{Introduction}

Institutions that function to provide advice and consideration to leaders of the country almost always exist in every country. In carrying out the role of advisor, an advisory institution can be double-edged, that is, being able to become an advisor to all existing, legal and broaddimensional institutions, or on the other hand only being an advisor from one particular state institution and having a dimension narrow[3].

In Indonesia, the history of the advisory institution can be seen from several periods. First, the Physical Revolution Period (1945-1949), namely the beginning of Indonesian independence. Second, the Union and Parliamentary Period (1950-1957). Third, the New Order Period (19661998). Fourth, the Reformation Period (1998-2003). Fifth, the Post-Reformation Period (20042006). Sixth, the Presidential Advisory Council since 2006.

The Law concerning the Presidential Advisory Council (Wantimpres) is stipulated by Presidential Decree Number 19 Year 2006 concerning the Wantimpres. Wantimpres replaced the function of the Supreme Advisory Council (DPA) which was dissolved in 2002. The 
Wantimpres is the only institution that according to Article 1 of Law Number 19 of 2006 is tasked with providing advice and consideration to the President in exercising the power of government[4].

In the Minister of Administrative Reform and Bureaucratic Reform Regulation Number 11 Year 2014 concerning the 2015-2019 Bureaucratic Reform Road Map, it is stated that the longterm goal of implementing bureaucratic reform in 2025 is that the government is expected to have moved on to dynamic governance[5]. At present, Indonesia is still in the position of performance-based bureaucracy.

This dynamic governance is expected to be able to deal with continual changes and be able to anticipate any changes. Likewise, what is expected from the Wantimpres is an advisory body for the President, who is able to provide advice and consideration to the President in leading the country to realize a just and prosperous society as mandated by the 1945 Constitution of the Republic of Indonesia.

In order to fulfill its obligations to give advice and consideration to the President, both requested and un requested, the advice and consideration given by the Wantimpres is inseparable from issues related to the intended development plan. The Wantimpres must be able to answer the challenges of globalization and environmental changes that directly or indirectly affect the organization, in this case of course that has an influence on the country of Indonesia. Dynamic governance can create leverage to get out of the vicious cycle of adversity with innovative solutions[6].

Dynamic governance can be achieved when adaptive policies, as well as two main levers to develop dynamic governance capabilities are able people and agile processes[2]. Regarding this matter, in order to prepare for the achievement of dynamic governance, the Wantimpres is expected to contain capable people and there is an agile process in dynamic governance that can anticipate changes in the environment, so that they are more able to compete among other countries. In addition to efforts to improve competitiveness, what the Government must face is the existence of the fourth or 4.0 industrial revolution which marks a new era in digitizing industries throughout the world. The challenge is to realize Indonesia 4.0, so as not to overtake the current of modernization.

In order to collect data and information as material for advice and consideration to the President, the Wantimpres stipulates 3 categories of issues, namely actual issues, strategic issues, and fundamental issues. Related to this, the following are the activities carried out by the Wantimpres as an effort to obtain material for the preparation of advice and considerations to be conveyed to the President, in the form of: 1) Limited Meeting, 2) Limited Discussion, 3) Study Team, 4) Domestic Work Visits, 5) Overseas Work Visits, 6) Aspiration Absorption and Audience, 7) Seminars[7].

The involvement of stakeholders in the Wantimpres meeting from Ministries / Institutions, as well as Local Governments (Provinces / Cities / Districts), private parties, Non-Governmental Organizations, academics in this case universities, and the House of Representatives / Regionals related to collaborative governance which has the main goal of bringing together several stakeholders with public agents in a togetherness, and conducting deeper cooperation with the division of tasks and functions of each part that has the same goals and ideology (the existence of shared vision among stakeholders, the community, and the perpetrators of these public agents)[8].

Based on Law Number 19 of 2006, the contents of the advice and considerations submitted by the Wantimpres to the President cannot be disseminated to anyone. The following is a recapitulation of the amount of advice and consideration that was submitted to the President since the Wantimpres Period I, II, and III, namely the period 2007 to 2017, as follows: 
Table 1. Recapitulation of the Number of Advice and Considerations submitted by the Wantimpres to the President

\begin{tabular}{|c|l|c|}
\hline No. & \multicolumn{1}{|c|}{$\begin{array}{c}\text { The Period of Submission } \\
\text { of Advice and Considerations }\end{array}$} & $\begin{array}{c}\text { Number of Advice and } \\
\text { Considerations }\end{array}$ \\
\hline 1. & Period I (April 2007 - October 2009) & 140 \\
\hline 2. & Period II (January 2010 - October 2014) & 255 \\
\hline 3. & Period III (January 2015 - December 2017) & 257 \\
\hline
\end{tabular}

Regarding the demand that the Wantimpres can always assist the President in facing challenges and changes that directly or indirectly affect governance, then in carrying out his duties, he provides advice and consideration through three dynamic abilities in the form of thinking ahead, thinking again, and thinking across. In doing this thinking process, it must be supported by two main levers to develop dynamic governance capabilities, namely able people and agile processes, in this case in the form of support from the Wantimpres Secretariat.

To be able to give advice and consideration to the President in realizing nawacita, the Wantimpres dynamic capabilities are needed. Dynamic capabilities as organizational capacity in changing routines and resources or core abilities to adapt to technological and environmental changes[2]. The capability component reflects how the Wantimpres mindset is based on three things, namely: thinking ahead, thinking again, and thinking across to create dynamic government.

The formation of the Members of the Wantimpres in the era of President Joko Widodo reaped responses from a number of Members of the House of Representatives Commission III, because there were no legal experts. Arsul Sani, PPP Politician also questioned President Joko Widodo's consideration so that there were no legal experts in the Wantimpres formation and stressed that legal experts in the Presidential Advisory Council were needed to provide different perspectives, especially for law-related policies. Another member of Commission III, Martin Hutabarat, also regretted President Joko Widodo's decision not to place legal experts in the Presidential Advisory Council. In fact, the existence of legal experts is important to give suggestions about the law before taking a policy or decision[9].

By looking at the following matters, namely the Wantimpres, is the only institution that is based on the mandate of the 1945 Constitution to provide advice and consideration to the President, the demands of the Wantimpres must be dynamic so that they can always give advice and considerations. involving relevant stakeholders to collect data and information, there is still a limitation in the Wantimpres Secretariat in providing service support to the Wantimpres even though on the other hand the Wantimpres Secretariat which provides able people and agile processes support is very important for Wantimpres in conducting collaborative processes. who was appointed as the Wantimpres and there were no experts in certain fields that should be needed, so the research questions were: 1 . What is the analysis of the capability of the Wantimpres organization? 2. How is the analysis of the dynamics of collaborative governance on the Wantimpres? 3. What is the Wantimpres collaborative governance design from a dynamic governance perspective?

From the research questions above, the objectives of this study are as follows: 1 . To analyze the capabilities of the Wantimpres organization. 2. To analyze the dynamics of collaborative 
governance in the Wantimpres. 3. To design Wantimpres collaborative governance from a dynamic governance perspective.

\section{Theoritical Review}

In order to collect data and information as material for the preparation of advice and considerations to the President, the Wantimpres involves several parties such as ministries / agencies, provincial / regency / city governments, academics, and other agencies or collaborating. The involvement of these other parties as stated by Ansell and Gash[8], which according to them collaborative governance is a government regulation in which one or more public institutions directly involve non-state stakeholders in collective decision-making processes that are formal, consensus oriented, and deliberative and aims to create or implement public policies or manage public programs or assets. They formulated collaborative governance up to its implementation.

Emerson, Nabatchi, and Balogh[10] and also Emerson and Nabatchi[1] responded to what was stated by Ansell and Gash[8]. They define collaborative governance more broadly as processes and structures in management as well as government and management policy decisions that involve people constructively across the boundaries of public bodies, government levels, and / or the public, private, and community to implement public goals that cannot be resolved. He further stated that collaborative governance is basically a condition when the government tries to fulfill public goals through collaboration with the private sector, community groups or individuals.

Related to this, it can be seen in the form of an integrative framework of collaborative governance in Figure 1. From the picture it can be seen that collaboration dynamics consists of three elements consisting of principled engagement, shared motivation, and joint capacity capacity for join action. The three elements described as three small circles (which represent the general system context, the collaborative governance regime, collaborative dynamics) work together interactively and repeatedly to produce collaborative actions in order to carry out the objectives of the collaborative governance regime. Such actions produce steps inside and outside the regime; thus, in the figure, arrows extend from action circles to show impacts (findings in the field) and potential adaptations (situations that are complex transformations or problems) both within the system context and within the collaborative governance regime itself.

From the picture, collaborative dynamics and collaborative action together form quality and overall level so that collaborative governance regimes can be developed effectively. The outer circle in Figure 1 is expressed in a darker color, is the context of the surrounding system or host that has political, legal, socio-economic, environmental and other influences that influence and are influenced by the collaboration governance regime. The context of this system produces opportunities and constraints and the influence of the dynamics of collaboration from the beginning and takes place from time to time. From the context of this system there are emerging drivers -in the form of: leadership, consequential incentives, interdependence, and uncertainty-, which helps initiate and regulate direction for collaborative governance regimes. A key feature of this framework is the collaborative governance regime. 


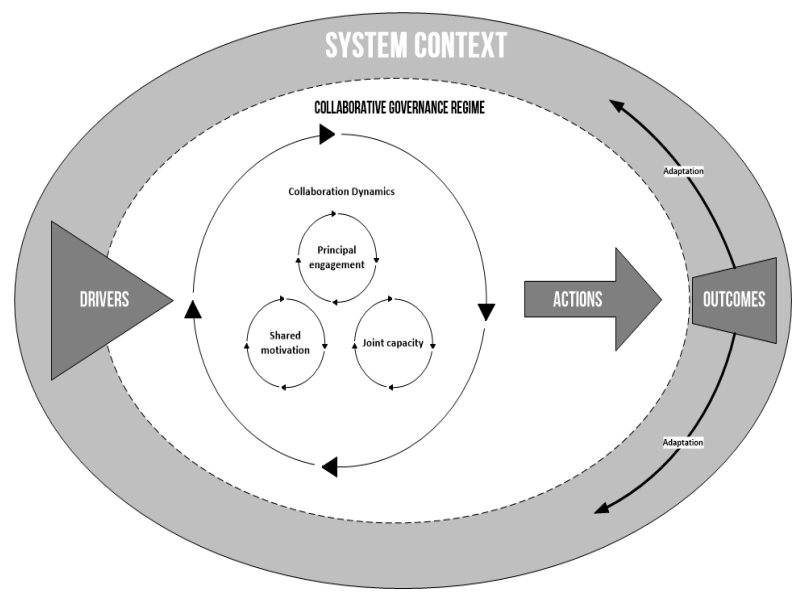

Source: Emerson and Nabatchi 2015[1]

Figure 1. Integrative Framework for Collaborative Governance

Organizations will face environmental dynamics and changes that ultimately require the ability of organizations to adapt to that environment[11]. In the face of ongoing changes, a dynamic organization is required, which is able to anticipate any changes that occur. In governance, it means that there is dynamic governance.

Wantimpres must be able to fulfill its obligations, namely giving advice and consideration to the President, both requested and not requested. Giving advice and consideration must be done on time and on target. Related to this, the Presidential Decree must be able to answer the challenges of globalization and environmental changes that directly or indirectly affect the Wantimpres organization, in this case of course that has an effect on the country of Indonesia.

For that, in carrying out their daily tasks, the Wantimpres is expected to carry out dynamic governance, that can anticipate environmental changes that occur. There are two elements in dynamic governance[2], first, namely the culture of government organizations that have five principles, and second, are the three cognitive abilities the basic learning process towards dynamic governance.

The first element, namely the culture of government organizations that have five principles, namely: integrity, not corruption, based on achievement, fair market oriented, pragmatic, and consisting of various ethnicities and beliefs. The foundation of cultural values and beliefs can work synergistically with a strong organizational ability to create dynamic governance and a system that allows continuous change. Cultural institutions can support or inhibit, facilitate or hinder the dynamics of policy making and implementation. Institutional culture involves how a nation feels its position in the world, how to articulate goals, and how values, beliefs and principles develop to guide decision-making and policy choices. In addition, strong organizational capabilities are needed to consider key policy issues as a whole and take effective action.

The second element, is in the form of three cognitive abilities a fundamental learning process towards dynamic governance. This includes thinking ahead, the ability to capture the initial signs about the direction of the development of the situation in the future that can affect the role and existence of a country and the ability to determine the right vision and mission. Thinking again is the ability and willingness to organize and evaluate policies that are in effect so that they can perform better. Thinking across is the ability to benchmark and openness to 
cross borders in order to be able to learn from the experiences of others so that they can introduce new ideas and concepts into the institutions they lead.

Furthermore, Neo and Chen[2] stated that the two elements must be supported by people who have the ability and the process is done well and agile processes as a driving factor. Capability of dynamic governance needs to be owned by all actors involved in the national development process, especially for those who act as change leaders[6].

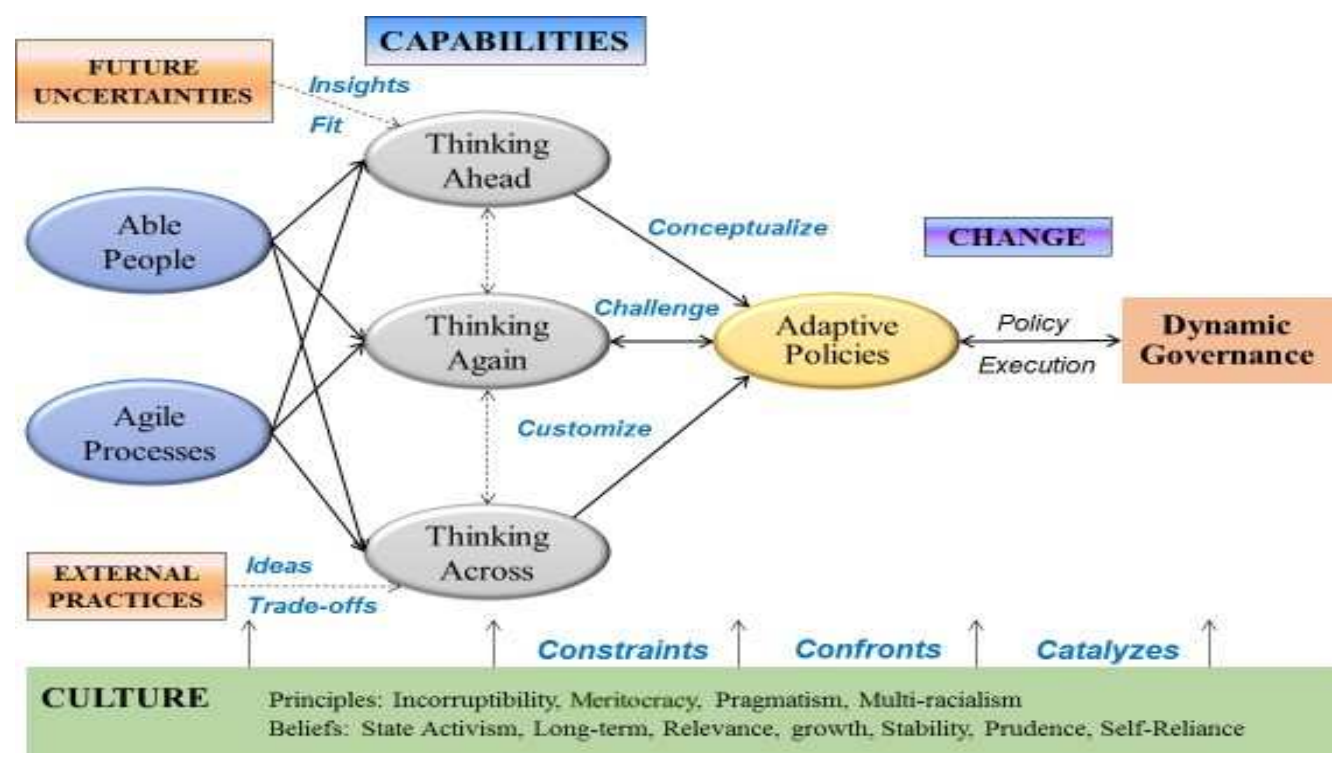

Source: Neo dan Chen (2007)[2]

Figure 2. Framework for Dynamic Governance

From the Picture of Dynamic Governance System Framework, it can be seen that dynamic governance on the right can be achieved if there is an adaptive policy. As a basis for dynamic governance, it is in the form of state institutional culture, which is found at the bottom of the picture.

The three dynamic capabilities of thinking ahead, thinking again, and thinking across, which lead to the policy that will be displayed are in the middle. The two main levers to develop dynamic governance capabilities are able people and agile processes where the process is displayed on the left side. The external environment influences the system of government through future uncertainties and external practices which are displayed as rectangles on the left.

Collaborative governance regimes consist of elements of principled engagement, shared motivation, and joint capacity. These three elements process dynamic collaboration, and occur continuously in collecting data and information. The aim is to arrange high-quality advice and considerations in an effort to produce adaptive policy. The lever component in the form of able people and agile processes is needed in dynamic collaborative. Able people and agile processes consist of Wantimpres Members and the Wantimpres Secretariat. Another element that influences dynamic collaboration is the process of thinking, namely thinking ahead, thinking again, and thinking accross. 
From the previous description, background and factual conditions, and various theories as above, the research conceptual framework is as shown in the following figure:

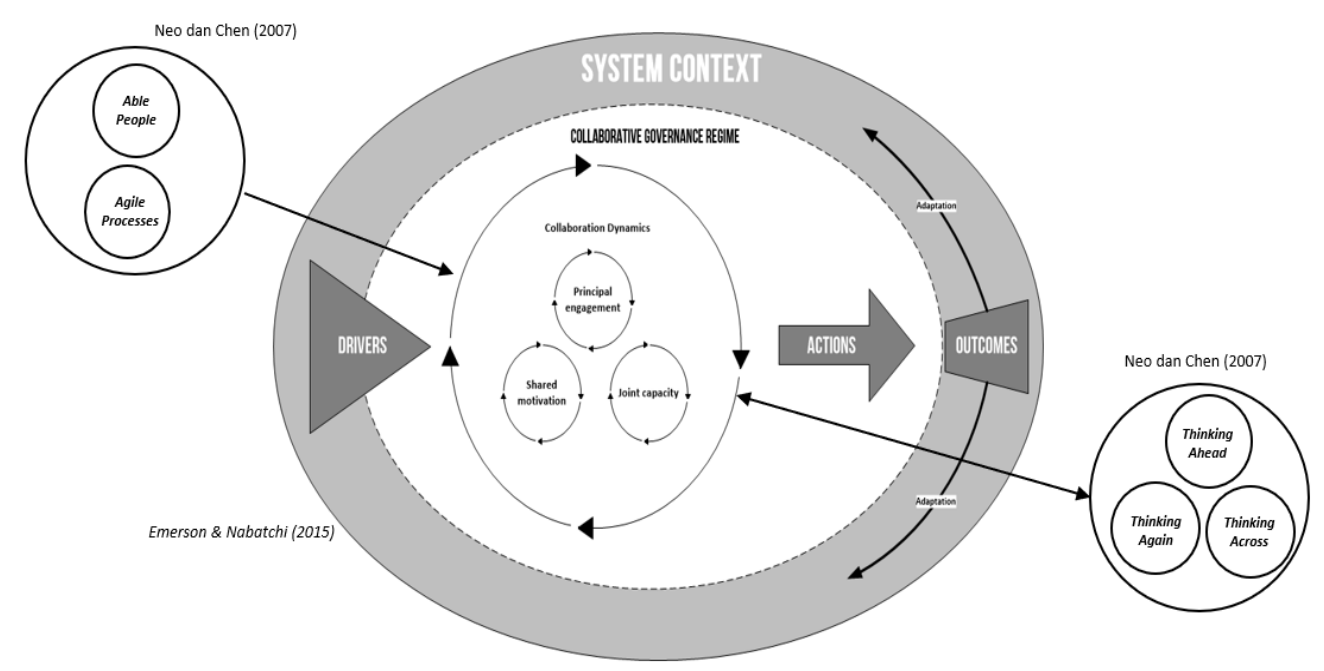

Source: Processed by researchers, Neo dan Chen (2007)[2], Emerson \& Nabatchi (2015)[1]

Figure 3. Research Conceptual Framework

To be able to find out in more detail related to the formulation of the main problem of this research, the operationalization of the concept was carried out. Operationalization of the concept is used as a guide for researchers by giving a boundary or meaning of a variable by detailing things that must be done by researchers in collecting data that is formed critically based on research questions in conducting qualitative analysis. In qualitative research variables are sometimes used, but often involve the use of ideas, themes or general concepts as a means to make generalizations[12].

In order to know the capabilities of Wantimpres, it was done by elaborating subvariable able people and agile processes. To be able to see how the dynamics of collaborative Wantimpres governance will be seen from the elements of collaborative governance in the form of elements of principled engagement, shared motivation, and joint capacity. Finally, to find out about the collaborative governance of Wantimpres from a dynamic governance perspective, it will be taken from the thinking process that consists of thinking ahead, thinking again, and thinking across.

From the things mentioned above, the design of collaborative Wantimpres governance will be made from a dynamic governance perspective. The design will contain that in the collaborative process is strongly influenced by dynamic capabilities and the ability to think.

The operational concept of this research can be seen in the following table: 
Table 2. Operationalization of the Research Concept

\begin{tabular}{|c|c|c|c|}
\hline NO. & VARIABEL & SUBVARIABEL & INDICATOR \\
\hline \multirow[t]{2}{*}{1.} & \multirow[t]{2}{*}{$\begin{array}{l}\text { Dynamic } \\
\text { Capability }\end{array}$} & Able people & $\begin{array}{l}\text { The election of a Member of the Presidential } \\
\text { Advisory Council } \\
\text { Strict division of the area of the Wantimpres } \\
\text { assignment } \\
\text { - Support of the Wantimpres Secretariat in the } \\
\text { Wantimpres activities }\end{array}$ \\
\hline & & $\begin{array}{ll}\text { b. } & \text { Agile } \\
& \text { Processes }\end{array}$ & $\begin{array}{l}\text { The participation of the Wantimpres in the } \\
\text { activities of the President } \\
\text { Intensity of the Wantimpres meeting with } \\
\text { the President } \\
\text { The existence and implementation of the } \\
\text { Standard Operating Procedures (SOP) of the } \\
\text { Wantimpres Secretariat }\end{array}$ \\
\hline \multirow[t]{3}{*}{2.} & \multirow[t]{3}{*}{$\begin{array}{l}\text { Elements of } \\
\text { Collaborative } \\
\text { Governance }\end{array}$} & $\begin{array}{ll}\text { a. } & \text { Principled } \\
& \text { Engagement }\end{array}$ & $\begin{array}{ll} & \text { Find information sources } \\
\circ & \text { Formulate the problem to be discussed } \\
\circ & \text { Consider } \\
\circ & \text { Determine alternative problem solving }\end{array}$ \\
\hline & & $\begin{array}{ll}\text { b. } & \text { Shared } \\
& \text { Motivation }\end{array}$ & $\begin{array}{l}\text { Trust each other between the speakers and } \\
\text { the Wantimpres } \\
\text { Mutual understanding in formulating policy } \\
\text { proposals } \\
\text { There is internal legitimacy from the highest } \\
\text { leadership } \\
\text { The sharing of commitments in the form of } \\
\text { conveying the actual conditions that occur in } \\
\text { the field }\end{array}$ \\
\hline & & $\begin{array}{ll}\text { c. } & \text { Joint } \\
& \text { Capacity - } \\
& \text { Capacity for } \\
& \text { joint action }\end{array}$ & $\begin{array}{ll}\circ & \text { Procedure arrangement } \\
\circ & \text { Leadership } \\
\circ & \text { Knowledge of each element involved } \\
\circ & \text { Resources in the Wantimpres }\end{array}$ \\
\hline \multirow[t]{3}{*}{3.} & \multirow[t]{3}{*}{$\begin{array}{l}\text { Process of } \\
\text { Thinking }\end{array}$} & $\begin{array}{l}\text { A The process } \\
\text { of thinking } \\
\text { ahead }\end{array}$ & $\begin{array}{l}\text { Determination of actual issues, strategic } \\
\text { issues, fundamental issues }\end{array}$ \\
\hline & & $\begin{array}{l}\text { b. The process } \\
\text { of thinking } \\
\text { again }\end{array}$ & $\begin{array}{ll} & \text { Activities to absorb views and aspirations } \\
\text { from related parties } \\
\text { There are proposals for redesigning policies } \\
\text { and programs }\end{array}$ \\
\hline & & $\begin{array}{l}\text { c. The process } \\
\text { of thinking } \\
\text { across }\end{array}$ & $\begin{array}{l}\text { There are activities or activities to do } \\
\text { benchmarking }\end{array}$ \\
\hline
\end{tabular}




\section{Methods}

This study aims to determine and analyze the capabilities of the Wantimpres organization, to analyze the dynamics of collaborative governance at the Wantimpres, and to design Wantimpres collaborative governance from a dynamic governance perspective. To answer research questions, the paradigm or approach used is post-positivism. This study uses a qualitative method. The source of qualitative research data consists of 3 types, namely interviews, observations, and documents[13]. The data for this study were collected using literary studies and in-depth interviews.

Informants in this study were selected based on subjects who had information related to the problems studied, namely related to collaborative governance, dynamic capabilities (able people and agile processes), the process of thinking (thinking ahead, thinking again, and thinking across) in order to provide advice and consideration to the President. The selection of informants in the study were those who had been and were directly involved with the activities carried out by the Wantimpres. The informant's elements consist of: Members of the Wantimpres, Members of the People's Representative Council (DPR), Academics, Officials of Ministries / Institutions, State-owned enterprises / Privat, and Officials and employees within the Wantimpres Secretariat. The data obtained from the interview results will be the primary data in this study.

The locus of this study is the Wantimpres as intended under Law Number 19 of 2006 concerning the Presidential Advisory Council, which includes the Wantimpres Member and the Wantimpres Secretariat.

\section{Result}

Based on the operational concept in question, the following is the result of the research of the Wantimpres dynamic capability, which is shown in the following Table:

Table 3. Dynamic Capability Research Results Matrix

\begin{tabular}{|c|l|l|l|}
\hline NO & SUBVARIABEL & \multicolumn{1}{|c|}{ CONDITION } & \multicolumn{1}{|c|}{ CONCLUTION } \\
\hline $\mathbf{1 .}$ & Able people & $\begin{array}{l}\text { The selection of members of the } \\
\text { Wantimpres in Period I and II was } \\
\text { dominated by experts and state officials, in } \\
\text { Period III dominated by political parties. }\end{array}$ & $\begin{array}{l}\text { The absence of the fields of } \\
\text { the Period III Wantimpres } \\
\text { Member, made limited } \\
\text { advice and considerations } \\
\text { needed by the President. } \\
\text { The Wantimpres Secretariat } \\
\text { still has limitations in } \\
\text { providing service support to } \\
\text { the Wantimpres, especially } \\
\text { in terms of substance. }\end{array}$ \\
& $\begin{array}{l}\text { The Wantimpres trial was conducted in } \\
\text { Period I and II, in Period III the fields were } \\
\text { carried out internally. }\end{array}$ & $\begin{array}{l}\text { The Secretariat's support has not fully met } \\
\text { the expectations of the Members of the } \\
\text { Wantimpres, especially those related to } \\
\text { services in the field of substance support }\end{array}$ & \\
\hline
\end{tabular}


Table 3. Dynamic Capability Research Results Matrix (continued)

\begin{tabular}{|c|c|c|c|}
\hline NO & SUBVARIABEL & CONDITION & CONCLUTION \\
\hline \multirow[t]{3}{*}{2.} & \multirow[t]{3}{*}{ Agile Processes } & $\begin{array}{l}\text { Participation in the activities of the } \\
\text { President is very limited in Period I and II, } \\
\text { but is often invited to attend the Cabinet } \\
\text { Session. In Period III he had never been } \\
\text { invited to take part in the Cabinet Session, } \\
\text { but he was often invited to participate in the } \\
\text { activities of the President. }\end{array}$ & \multirow{3}{*}{$\begin{array}{l}\text { The president in each period } \\
\text { has a different method and } \\
\text { treatment in terms of } \\
\text { involving the Wantimpres } \\
\text { in their activities in running } \\
\text { the government. } \\
\text { The more intensive } \\
\text { involvement of the } \\
\text { Wantimpres in each activity } \\
\text { of the President will } \\
\text { facilitate the Wantimpres to } \\
\text { obtain information directly } \\
\text { from the President. } \\
\text { Support for services to the } \\
\text { Wantimpres by the } \\
\text { Wantimpres Secretariat in } \\
\text { general has been felt to be } \\
\text { adequate. What still needs } \\
\text { to be improved is service in } \\
\text { the field of substance and } \\
\text { for the technical and } \\
\text { administrative fields, } \\
\text { optimization is still needed } \\
\text { that utilizes IT. }\end{array}$} \\
\hline & & $\begin{array}{l}\text { The intensity of meetings with the President } \\
\text { was very limited in Periods I and II. } \\
\text { In Period III, Members of the Wantimpres } \\
\text { met more frequently with the President. }\end{array}$ & \\
\hline & & $\begin{array}{l}\text { The activities facilitated by the Secretariat } \\
\text { in supporting the Wantimpres were } \\
\text { adequate, but informal meeting activities } \\
\text { and incognito activities still could not be } \\
\text { facilitated by Secretariat of Wantimpres. } \\
\text { The Wantimpres Secretariat has } 8 \text { Macro } \\
\text { SOPs and } 46 \text { Micro SOPs. } \\
\text { The SOP is not always implemented by the } \\
\text { Wantimpres Secretariat because of frequent } \\
\text { requests for sudden service from the } \\
\text { Members of the Wantimpres. }\end{array}$ & \\
\hline
\end{tabular}

Source: Researcher Research

Tthe results of research on Wantimpres collaborative governance can be seen in Table 4:

Table 4. Collaborative Governance Research Matrix

\begin{tabular}{|c|c|c|c|}
\hline NO & SUBVARIABEL & CONDITION & CONCLUTION \\
\hline 1. & $\begin{array}{l}\text { Principled } \\
\text { Engagement }\end{array}$ & $\begin{array}{l}\text { In general this subvariable is as expected. } \\
\text { However, in one element related to who is the } \\
\text { source of information sometimes it still does not } \\
\text { fully meet expectations. } \\
\text { This is because if the invited person has a } \\
\text { different view from the other invitation, usually } \\
\text { one of the parties is not present. }\end{array}$ & \multirow{2}{*}{$\begin{array}{l}\text { Collaborative } \\
\text { governance in the } \\
\text { Wantimpres } \\
\text { almost meets three } \\
\text { elements. } \\
\text { What still needs } \\
\text { attention is the } \\
\text { element of } \\
\text { principled } \\
\text { engagement, } \\
\text { where the speakers } \\
\text { present often } \\
\text { represent invited } \\
\text { parties. }\end{array}$} \\
\hline 2. & Shared Motivation & $\begin{array}{l}\text { In general this subvariable is as expected. } \\
\text { However, in the element of mutual } \\
\text { understanding in formulating policy proposals } \\
\text { there is not always a common opinion. This is } \\
\text { possible because the material that is the subject } \\
\text { of discussion can be very broad, there are } \\
\text { different policies in each agency }\end{array}$ & \\
\hline
\end{tabular}


Table 4. Collaborative Governance Research Matrix (continued)

\begin{tabular}{|c|l|l|l|}
\hline NO & SUBVARIABEL & \multicolumn{1}{c|}{ CONDITION } & CONCLUTION \\
\hline 3. & $\begin{array}{l}\text { Joint Capacity }- \\
\text { Capacity for Joint } \\
\text { Action }\end{array}$ & $\begin{array}{l}\text { In general this subvariable is as expected. } \\
\text { However, in the element there is a third element, } \\
\text { namely joint capacity, it is revealed that the } \\
\text { available resources related to the budget have } \\
\text { not fully been able to support the Wantimpres } \\
\text { activities. }\end{array}$ & $\begin{array}{l}\text { In the element of } \\
\text { shared motivation, } \\
\text { understanding is } \\
\text { needed. In the joint } \\
\text { capacity element, } \\
\text { resources that can } \\
\text { fully support the } \\
\text { Wantimpres activities } \\
\text { are needed }\end{array}$ \\
\hline
\end{tabular}

Source: Researcher Research

From the results of identification of the title or matter of advice and consideration submitted to the President, then if grouped based on the category of issues as Table 5. From the Table, it can be stated that the Period III Wantimpres is more productive in giving advice to the President.

Table 5. Recapitulation of Number of Advice and Considerations which was conveyed by the Wantimpres to the President based on the Issue Category

\begin{tabular}{|c|l|r|r|r|r|}
\hline \multirow{2}{*}{ No. } & \multirow{2}{*}{ Wantimpres Period } & \multirow{2}{*}{$\begin{array}{c}\text { Number of Advice } \\
\text { and Considerations }\end{array}$} & \multicolumn{3}{|c|}{ Issue Catagori } \\
\cline { 5 - 6 } & & 140 & 59 & 71 & 10 \\
\hline 1. & Period I & 255 & 118 & 122 & 15 \\
\hline 2. & Period II & 257 & 76 & 164 & 17 \\
\hline 3. & Period III & & Strategic & \multicolumn{1}{c|}{ Fundamentals } \\
\hline
\end{tabular}

Source: Processed from the DEwan Pertimbangan Presiden Task Implementation Report 2007 to 2017[7]

The dynamics of the process of thinking in the Wantimpres based on the results of the research can be seen in Table 6 below: 
Table 6. Dynamics of the Thinking Process in Wantimpres

\begin{tabular}{|c|c|c|c|}
\hline $\begin{array}{l}\text { Capability } \\
\text { Element } \\
\text { (Driver) }\end{array}$ & Thinking Ahead & Thinking Again & Thinking Across \\
\hline \multirow{2}{*}{$\begin{array}{c}\text { Paths } \\
\text { (Policy Choises, } \\
\text { Execution, } \\
\text { Adaptation \& } \\
\text { Innovation) }\end{array}$} & $\begin{array}{c}\text { Investment } \\
\text { (refresh goals) }\end{array}$ & $\begin{array}{l}\text { Improvements } \\
\text { (better quality) }\end{array}$ & $\begin{array}{c}\text { Innovations } \\
\text { (new ideas) }\end{array}$ \\
\hline & $\begin{array}{l}\text { Giving advice and } \\
\text { consideration to the } \\
\text { President, both } \\
\text { requested and } \\
\text { unsolicited, which is } \\
\text { continuous in } \\
\text { responding to actual, } \\
\text { strategic and } \\
\text { fundamental issues as } \\
\text { required by the } \\
\text { President }\end{array}$ & $\begin{array}{l}\text { Efforts towards improving the } \\
\text { quality of advice and } \\
\text { consideration are the main focus } \\
\text { of the Wantimpres on an ongoing } \\
\text { basis. } \\
\text { Example: } \\
\text { recommendations related to } \\
\text { handling problems in the } \\
\text { economy today may be very } \\
\text { different from the previous time } \\
\text { and the next }\end{array}$ & $\begin{array}{l}\text { The innovations and } \\
\text { debureaucratization that are } \\
\text { currently being implemented related } \\
\text { to agile processes include: } \\
\text { - Use of ownCloud and S-box } \\
\text { Setneg folder sharing / repository } \\
\text { platforms in the preparation of } \\
\text { the Database Resource Person (in } \\
\text { the form of Ms. Access) and } \\
\text { Recap of the Activities of the } \\
\text { Wantimpres Member (Ms. } \\
\text { Excel) } \\
\text { - Application of Resource } \\
\text { Management (Alona) in } \\
\text { Supporting the Implementation } \\
\text { of Wantimpres Activities. } \\
\text { Related to able people, individually, } \\
\text { every PNS Secretariat of the } \\
\text { Presidential Secretariat has } \\
\text { volunteered to participate in training } \\
\text { every year. Organizationally, the } \\
\text { Wantimpres Secretariat is still not } \\
\text { fully paying attention to improving } \\
\text { HR competencies both through } \\
\text { training and non-training activities. }\end{array}$ \\
\hline \multirow[t]{2}{*}{$\begin{array}{c}\text { Processes (Agile } \\
\text { Structures \& } \\
\text { Systems) }\end{array}$} & $\begin{array}{c}\text { Strategizing } \\
\text { (exploring \& } \\
\text { anticipatory) } \\
\end{array}$ & $\begin{array}{c}\text { Redesigning } \\
\text { (review \& analyzing) }\end{array}$ & Discovering \& Experimenting \\
\hline & $\begin{array}{l}\text { Advice and } \\
\text { considerations are given } \\
\text { based on priority scale. } \\
\text { After the first priority is } \\
\text { finished immediately } \\
\text { move on to the next } \\
\text { priority }\end{array}$ & $\begin{array}{l}\text { Wantimpres cares about his own } \\
\text { needs, among others can propose } \\
\text { a hearing to the President } \\
\text { established by Presidential } \\
\text { Decree as the previous period. } \\
\text { The Wantimpres Secretariat } \\
\text { proposes an institutional } \\
\text { evaluation bearing in mind that } \\
\text { the organization of the } \\
\text { Wantimpres Secretariat is formed } \\
\text { to serve the Wantimpres } \\
\text { Members whose facilities are not } \\
\text { yet at the level of the State } \\
\text { Minister } \\
\text { Besides this, thinking again also } \\
\text { focuses on policy redesigning. } \\
\text { Wantimpres must be able to push } \\
\text { the quality of draft law, in which } \\
\text { the perspective of punishment is } \\
\text { fair and upholds human rights, } \\
\text { and eliminates various legal } \\
\text { loopholes that can lead to other } \\
\text { violations of the law. }\end{array}$ & $\begin{array}{l}\text { In thinking across, comparative } \\
\text { study and benchmarking activities } \\
\text { are effective steps for Wantimpres } \\
\text { to learn from other agencies as a } \\
\text { basis for continuous evaluation. } \\
\text { Thinking across can be in the form } \\
\text { of adopting, adapting, or replicating } \\
\text { innovation, or debureaucratization } \\
\text { carried out by other agencies / } \\
\text { institutions. } \\
\text { In an effort to improve quality } \\
\text { capable people in preparing more } \\
\text { qualified advice and consideration } \\
\text { reports to the President, the } \\
\text { Wantimpres can collaborate with } \\
\text { UNDP and the Government of } \\
\text { Singapore regarding procedures for } \\
\text { writing reports, making minutes, } \\
\text { transcripts, minutes of meetings that } \\
\text { are effective and efficient. }\end{array}$ \\
\hline
\end{tabular}


Table 6. Dynamics of the Thinking Process in Wantimpres (continued)

\begin{tabular}{|c|c|c|c|}
\hline $\begin{array}{l}\text { Capability } \\
\text { Element } \\
\text { (Driver) }\end{array}$ & Thinking Ahead & Thinking Again & Thinking Across \\
\hline \multirow[b]{2}{*}{$\begin{array}{l}\frac{\text { People }}{\text { (Able }} \\
\text { Leadership, } \\
\text { Recruitment, } \\
\text { Renewal \& } \\
\text { Retention) }\end{array}$} & Scenario Builder & Problem Solver & Knowledge Broker \\
\hline & $\begin{array}{l}\text { Members of the } \\
\text { Wantimpres and } \\
\text { Secretariat have the } \\
\text { ability as scenario } \\
\text { builders to be able to } \\
\text { map issues that are } \\
\text { actual, strategic, and } \\
\text { fundamental, and } \\
\text { priority issues must be } \\
\text { immediately adjusted } \\
\text { based on urgency, } \\
\text { seriousness, and growth } \\
\text { (USG) }\end{array}$ & $\begin{array}{l}\text { Members of the Wantimpres and } \\
\text { the Wantimpres Secretariat are } \\
\text { part of the nation's problem } \\
\text { solver in accordance with their } \\
\text { respective roles and positions. }\end{array}$ & $\begin{array}{l}\text { Wantimpres is a knowledge broker } \\
\text { To realize the Wantimpres } \\
\text { knowledge broker has conducted } \\
\text { data and information collection } \\
\text { activities through limited meetings, } \\
\text { limited discussions, seminars } \\
\text { involving experts to obtain data and } \\
\text { information to solve problems. } \\
\text { In addition, the Wantimpres also } \\
\text { absorbs views and audiences, as } \\
\text { well as working visits to the regions } \\
\text { to see actual issues directly in the } \\
\text { field, and conduct working visits } \\
\text { abroad to see first hand the } \\
\text { development of other countries in } \\
\text { building their nation and absorb } \\
\text { international issues. }\end{array}$ \\
\hline
\end{tabular}

Source: Processed from Neo and Chen (2007)[2] and Research Results

From the things mentioned above, a link between the thinking process and collaborative governance can be made, which if described will be seen in Table 7 as follows:

Table 7. Linkages between the Thinking Process and Collaborative Governance

\begin{tabular}{|c|c|c|c|c|}
\hline Collaborative & $\begin{array}{l}\text { Thinking } \\
\text { ernance }\end{array}$ & Thinking Ahead & Thinking Again & Thinking Across \\
\hline $\begin{array}{l}\text { principled } \\
\text { engagement }\end{array}$ & $\begin{array}{l}\text { discovery, } \\
\text { definiting, } \\
\text { deliberation, } \\
\text { determination }\end{array}$ & $\begin{array}{l}\text { As a form of thinking } \\
\text { ahead, the Wantimpres } \\
\text { has done principled } \\
\text { engagement, by always } \\
\text { discovering and } \\
\text { definiting actual issues, } \\
\text { determined through } \\
\text { mapping strategic } \\
\text { issues. It can be said, } \\
\text { every actual issue that } \\
\text { becomes the priority } \\
\text { scale of the Wantimpres } \\
\text { is part of national / } \\
\text { global strategic issues. } \\
\text { However, not every } \\
\text { strategic issue is the } \\
\text { actual issue of the } \\
\text { Wantimpres. }\end{array}$ & $\begin{array}{l}\text { Thinking again is a } \\
\text { continuous and sustainable } \\
\text { activity that requires } \\
\text { principled engagement in } \\
\text { the dynamics of } \\
\text { collaborative governance, } \\
\text { especially in finding and } \\
\text { defining weaknesses, } \\
\text { challenges, strengths, and } \\
\text { threats faced by the } \\
\text { Indonesian people. In } \\
\text { other words, Wantimpres } \\
\text { always updates the map of } \\
\text { the nation's problems in } \\
\text { actual issues, strategic } \\
\text { issues, and fundamental } \\
\text { issues. } \\
\text { Wantimpres is expected to } \\
\text { be proactive in } \\
\text { formulating new policies } \\
\text { and evaluating existing } \\
\text { policies. }\end{array}$ & $\begin{array}{l}\text { Thinking activity is an } \\
\text { activity to see the } \\
\text { progress and innovation } \\
\text { that has been done by } \\
\text { other parties. This } \\
\text { activity certainly requires } \\
\text { a principled engagement } \\
\text { in finding and defining } \\
\text { innovations that have } \\
\text { been carried out by other } \\
\text { agencies / institutions, } \\
\text { which need to be } \\
\text { adopted, adapted, or } \\
\text { replicated in accordance } \\
\text { with the needs of the } \\
\text { Wantimpres organization. } \\
\text { Before determining the } \\
\text { innovation chosen, } \\
\text { deliberation is carried out } \\
\text { involving the relevant } \\
\text { parties. }\end{array}$ \\
\hline
\end{tabular}


Table 7. Linkages between the Thinking Process and Collaborative Governance (continued)

\begin{tabular}{|c|c|c|c|c|}
\hline \multicolumn{2}{|c|}{ Collaborative Governance } & Thinking Ahead & Thinking Again & Thinking Across \\
\hline $\begin{array}{l}\text { shared } \\
\text { motivation }\end{array}$ & $\begin{array}{l}\text { mutual trust, } \\
\text { mutual } \\
\text { understanding, } \\
\text { internal } \\
\text { legitimacy, } \\
\text { share } \\
\text { commitment }\end{array}$ & $\begin{array}{l}\text { To be able to think forward } \\
\text { (visionary and anticipatory) } \\
\text { which is the core of thinking } \\
\text { ahead, between the President } \\
\text { and Wantimpres must build } \\
\text { mutual trust (mutual } \\
\text { understanding), as well as } \\
\text { between the Wantimpres with } \\
\text { the Secretariat of the } \\
\text { Wantimpres, and between the } \\
\text { Wantimpres and stakeholders. }\end{array}$ & $\begin{array}{l}\text { To guarantee thinking } \\
\text { again, mutual trust and } \\
\text { mutual understanding are } \\
\text { needed. } \\
\text { Thinking again activities } \\
\text { aimed at sustainable } \\
\text { improvement are shown } \\
\text { by the consideration of the } \\
\text { Wantimpres that is } \\
\text { continually requested or } \\
\text { not requested by the } \\
\text { President. } \\
\text { Consideration of the } \\
\text { Wantimpres meets quality } \\
\text { to get internal legitimacy } \\
\text { from the President and the } \\
\text { Secretariat Head of the } \\
\text { Presidential Institution } \\
\text { (State Secretary, Secretary } \\
\text { and Chief of Office of the } \\
\text { Presidential Staff). } \\
\text { With the quality of advice } \\
\text { and consideration of the } \\
\text { Wantimpres, it shows to } \\
\text { stakeholders that the } \\
\text { Wantimpres is fully } \\
\text { committed (share } \\
\text { commitment) to assist the } \\
\text { President in running the } \\
\text { government of the } \\
\text { country, especially related } \\
\text { to the realization of } \\
\text { Nawacita. }\end{array}$ & $\begin{array}{l}\text { Thinking across } \\
\text { activities become } \\
\text { more meaningful if } \\
\text { the activities that } \\
\text { exist in share } \\
\text { motivation, namely: } \\
\text { mutual trust, mutual } \\
\text { understanding, } \\
\text { internal legitimacy, } \\
\text { share commitment, } \\
\text { can be fulfilled }\end{array}$ \\
\hline $\begin{array}{l}\text { Joint } \\
\text { capacity - } \\
\text { Capacity for } \\
\text { joint action }\end{array}$ & $\begin{array}{l}\text { procedural/ } \\
\text { institutional } \\
\text { arrangements, } \\
\text { leadership, } \\
\text { knowledge, } \\
\text { resources }\end{array}$ & $\begin{array}{l}\text { During this time, the } \\
\text { Wantimpres Secretariat was } \\
\text { considered visionary (yet } \\
\text { visionary) but not yet } \\
\text { anticipatory. For example to } \\
\text { meet the Wantimpres analysis } \\
\text { needs, the Secretariat has not } \\
\text { anticipated quality internet } \\
\text { needs even the Chairperson of } \\
\text { the Wantimpres also stated that } \\
\text { the internet is still slow. } \\
\text { Considering that the } \\
\text { assignment of the members of } \\
\text { the Wantimpres' duties is still } \\
\text { internal and does not explicitly } \\
\text { show specialization, making } \\
\text { advice and considerations on } \\
\text { certain issues (foreign and } \\
\text { legal) cannot be fully fulfilled. }\end{array}$ & $\begin{array}{l}\text { General functional } \\
\text { positions at the } \\
\text { Wantimpres Secretariat } \\
\text { have not all been filled. } \\
\text { This made outsourcing } \\
\text { workers who were } \\
\text { supposed to be in charge } \\
\text { of providing service } \\
\text { support as security } \\
\text { personnel, drivers, and } \\
\text { service personnel to fill } \\
\text { the empty position map. } \\
\text { In addition, the limited } \\
\text { capacity of the Secretariat } \\
\text { in providing substantial } \\
\text { support made several } \\
\text { members of the } \\
\text { Wantimpres recruit } \\
\text { independently from } \\
\text { outside the Wantimpres. }\end{array}$ & $\begin{array}{l}\text { Wantimpres must be } \\
\text { able to utilize limited } \\
\text { resources in terms of } \\
\text { quality and quantity, } \\
\text { so that the } \\
\text { Wantimpres must be } \\
\text { able to think } \\
\text { innovatively, for } \\
\text { example HR } \\
\text { limitations are } \\
\text { overcome by } \\
\text { creating applications } \\
\text { about ready-to- } \\
\text { support data }\end{array}$ \\
\hline
\end{tabular}

Source: processed from Neo and Chen (2007)[2], Emerson and Nabatchi (2015)[1], research results 
From the above, in Figure 4 the following is the design of collaborative Wantimpres governance from a dynamic governance perspective. Images that are designs are processed by researchers from Neo and Chen[2] and Emerson and Nabatchi[1] as well as the results of research as previously described.

In the picture it can be seen that in the collaborative governance regime there is a dynamic collaborative consisting of elements of principled engagement, shared motivation, and joint capacity. The elements contained in each of these elements work together dynamically to strengthen, and the three elements work together interactively and repeatedly to strengthen each other in the dynamics of collaboration[1].

This process is ongoing in collecting data and information by involving relevant stakeholders. The activity was carried out through the Wantimpres activities in the form of Limited Meeting, Limited Discussion, Study Team, Domestic Work Visit, Overseas Working Visit, Aspiration Absorption and Audience, Seminar. In the implementation of these activities invite stakeholders from related institutions and / or resource persons who are experts in their fields, whose implementation is guided by existing SOPs in the Wantimpres.

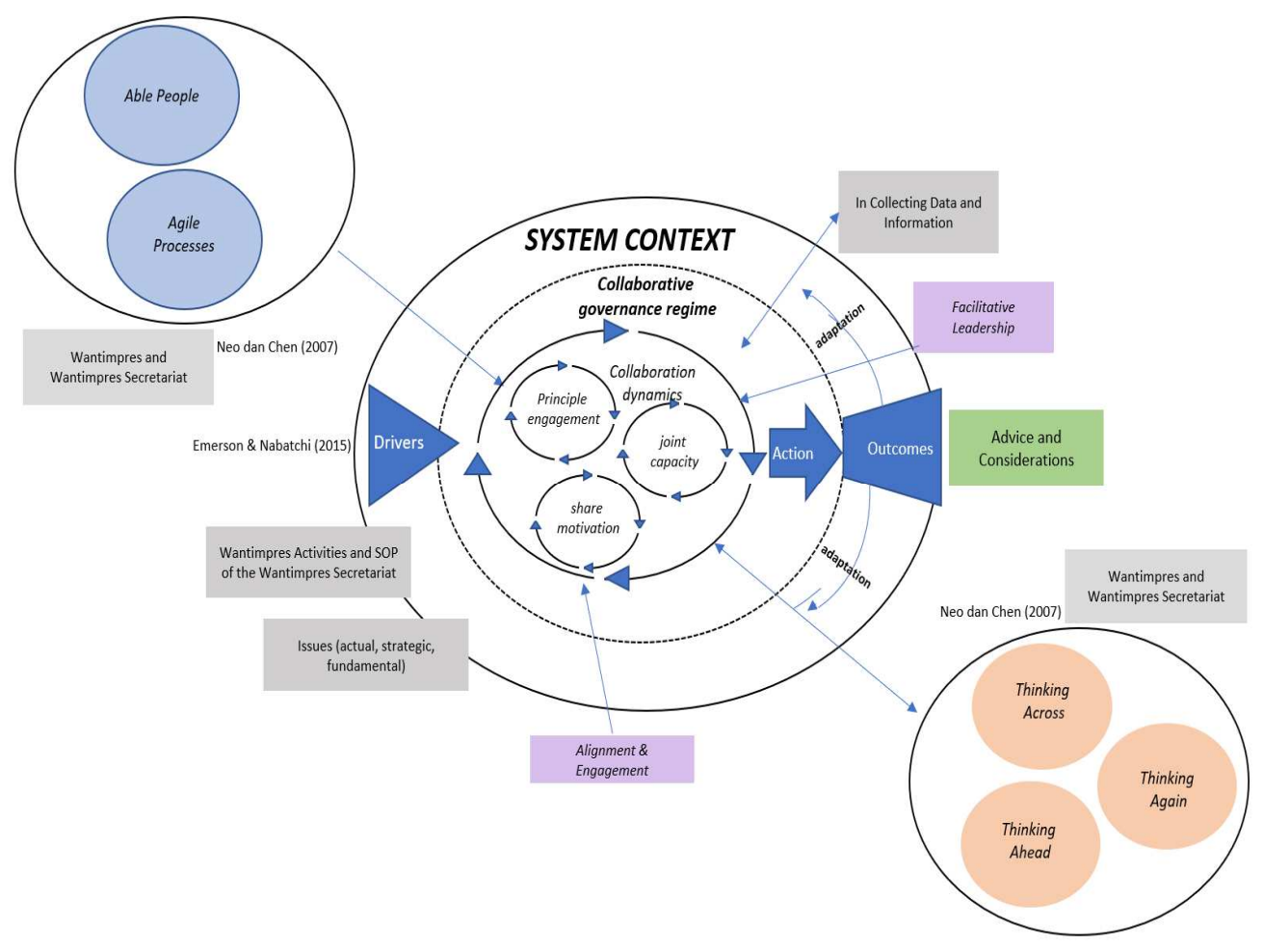

Source: results of research processed from Neo and Chen (2007)[2], Emerson and Nabatchi (2015)[1]

Figure 4. The Design of Collaborative Governance of The Presidential Advisory Council From Dynamic Governance Perspectives 
The issues discussed are in the form of issues that require discussion as input for the President, which can be in the form of actual issues, strategic issues, or fundamental issues. The issues that become the topic of the Wantimpres can be in the form of assignments from the President to discuss a particular issue, and can be in the form of initiatives from the Wantimpres.

In the implementation of the process, alignment with relevant stakeholders is needed, and finally an engagement must be made in the effort to arrange high-quality advice and consideration in an effort to produce adaptive policies produced by the government.

From the results of the study also obtained information on the importance of facilitative leadership. Facilitative leadership is the role of Chairperson of the Wantimpres in each period as the leader of the other Wantimpres Members. The Chairperson of the Wantimpres is very instrumental in equating and bringing together various inputs from other Wantimpres Members in terms of producing collective advice and consideration that will be conveyed to the President. This role becomes very important considering that the other Members of the Wantimpres consisting of 8 (eight) are leaders with different experiences, knowledge and insights in their respective fields.

In collaborating, we need a lever component in the form of able people and agile processes as dynamic capabilities needed to create dynamic collaboration. This lever component is the Wantimpres (Chair and Member) and the Wantimpres Secretariat, which is able people, and the processes carried out in an effort to collect data and information for the preparation of advice and consideration to the President which is part of agile procesess.

Furthermore, other elements that greatly influence dynamic collaboration in the process of formulating advice and consideration are carried out through a process of thinking, which includes thinking ahead, thinking again, and thinking across. This process of thinking is at the core of the activities carried out by the Wantimpres in the framework of preparing advice and considerations to be presented to the President.

Next, the results of the action in the form of continuously carried out actions in the collaboration process will produce outcomes in the form of advice and considerations that will be submitted to the President by the Wantimpres Member.

\section{Conclusion}

The capability of the Wantimpres organization in the process of collecting data and information as material for preparing advice and considerations to the President is inseparable from able people and agile processes contained therein. The demands of able people are not only for the Members of the Wantimpres, but also for the Wantimpres Secretariat which is inherent in the Wantimpres activities. The absence of the fields of the Members of the Wantimpres in the era of President Joko Widodo, made the limited advice and considerations needed by the President, especially in the field of foreign relations / international issues and law. The Wantimpres Secretariat still has limitations in providing service support to the Wantimpres, especially in terms of substance. This makes some Members of the Wantimpres have a think tank that they carry themselves. Agile Processes for activities facilitated by the Secretariat in supporting the Wantimpres in collecting data and information for the preparation of advice / considerations were felt to be adequate. However, informal meetings in the absorption of community aspirations (such as meetings at coffee shops outside the office) carried out by Members of the Wantimpres including incognito activities, still cannot be facilitated by the Wantimpres Secretariat. In addition, the SOP of the Wantimpres Activities often cannot be 
carried out because the application for facilitation of sudden activities by the Wantimpres.

Collaborative governance in Wantimpres in general has fulfilled three elements, namely principled engagement, shared motivation, and the capacity to produce joint capacity - capacity for joint action, which aims to produce advice and consideration quality for the President regarding actual issues, strategic issues, and fundamental issues.

In the element of principled engagement, Wantimpres has a role in determining the issues to be discussed up to determining the point of view to be used. In this activity, stakeholders exchanged opinions, straightened out the information that existed until there was a meeting point and even became a problem solving solution between the stakeholders themselves, and if there was a dispute then the Wantimpres was the final determinant. What still needs attention to the element of principled engagement, is where the speakers present often represent the invited party.

Shared motivation is realized because stakeholders believe in the Wantimpres, among others, that their input is of internal Wantimpres consumption and not to be published. This sometimes makes stakeholders become dependent and puts high hopes on the Wantimpres to solve existing problems. In this shared motivation element there is still a need for common understanding among stakeholders who collaborate.

In terms of capacity to produce joint action, the results of input from stakeholders are not only beneficial to the Wantimpres, but also to the stakeholders themselves. In the joint capacity element, resources are still needed that can fully support the Wantimpres activities.

One form of collaboration related to data collection and information that already exists in written form in the form of a memorandum of understanding is between Wantimpres and BPS (Central Bureau of Statistics).

The research produced a Wantimpres collaborative governance model from the perspective of dynamic governance, namely there is a leverage component that is very influential on the collaboration process in the form of able people and agile processes, namely Wantimpres and the Wantimpres Secretariat. In addition, there are also other elements that influence collaboration, namely thinking processes, which include thinking ahead, thinking again, and thinking across in the process of formulating advice and consideration.

In the collaboration process also requires the need for alignment with relevant stakeholders, and also creates a close relationship (engagement) in the effort to arrange high-quality advice and consideration that will be conveyed to the President.

There is a need to express the Presidential Decree that is legally stipulated (by Presidential Decree) and talent management in the selection of Wantimpres Members to create able people in giving advice and consideration to the President. There needs to be a commitment from the Leader (both at the Member level of the Wantimpres and the Wantimpres Secretariat) so that all services performed can be in accordance with the SOP, to ensure better quality services. The SOP that currently exists at the Wantimpres Secretariat needs to be evaluated regularly and periodically, as well as adjustments as needed or according to existing needs to be able to provide maximum services to the Wantimpres.

The Presidential Advisory Council must endeavor to support the collaborative process to obtain information from stakeholders in order to create conditions in which high-quality advice and consideration delivered to the President. The Wantimpres Secretariat needs to identify and re-evaluate the form of activities in an effort to collect data and information in accordance with the needs of the Presidential Advisory Council. This is intended to ensure that every Wantimpres activity can be supported by an adequate budget.

The leadership must immediately be able to identify obstacles to overcome the obstacles that the Wantimpres can make in the process of thinking (thinking ahead, thinking again, 
thinking across), enlarging the role of leverage factors (able people and agile processes), and strengthening alignment and engagement from stakeholders in the collaborative governance process.

\section{References}

[1] K. Emerson, And, and T. Nabatchi, Collaborative Governance Regimes. 2015.

[2] G. Neo, Boon Siong and Chen, Dynamic Governance: Embedding Culture, Capalities and Change in Singapore. 2007.

[3] Z. Ghazali, "DPA Dalam Sejarah Konstitusi Republik," J. Huk. dan Pembang., vol. 16 , no. 5 , pp. 450-468, 1986.

[4] Republik Indonesia, Undang-Undang Republik Indonesia Nomor 19 Tahun 2006 tentang Dewan Pertimbangan Presiden. 2006.

[5] Kementerian Pendayagunaan Aparatur Negara dan Reformasi Birokrasi, Peraturan Menteri Pendayagunaan Aparatur Negara dan Reformasi Birokrasi Republik Indonesia Nomor 11 Tahun 2015 tentang Road Map Reformasi Birokrasi Nasional 2015-2019. 2015.

[6] B. S. Kasim, Azhar. Huseini, Martani. Anwar, Rozan. Neo, Merekonstruksi Indonesia: Sebuah Perjalanan Menuju Dynamic Governance. Penerbit Buku Kompas, 2015.

[7] Dewan Pertimbangan Presiden, Laporan Pelaksanaan Tugas Dewan Pertimbangan Presiden (Tahun 2007 s.d. 2017). Jakarta: Dewan Pertimbangan Presiden.

[8] C. Ansell and A. Gash, "Collaborative governance in theory and practice," J. Public Adm. Res. Theory, 2007.

[9] www.hukumonline.com, "https://www.hukumonline.com/berita/baca/lt54be25a84ee17/tiada-ahli-hukum-formasi-wantimpres-dikritik/," 2015. .

[10] K. Emerson, T. Nabatchi, and S. Balogh, "An integrative framework for collaborative governance," J. Public Adm. Res. Theory, vol. 22, no. 1, pp. 1-29, 2012.

[11] S. P. Robbins, Organizational Behavior, Concept Controversies and Applications, 7th ed. Prentice Hall International Edition Eaglewood Cliffs. NY: Prentice-Hall, 1996.

[12] W. L. Neuman, Metodologi Penelitian Sosial: Pendekatan Kualitatif dan Kuantitatif, 7th ed. PT Indeks, Jakarta, 2013.

[13] M. Q. Patton, Qualitative Evaluation and Research Methods. New Delhi: Sage Publication. New Delhi: Sage Publication, 1990. 